\title{
A Case of Multiple Pharyngocutaneous Fistulae Following Post-Operative Concurrent Chemoradiotherapy for Oropharyngeal Cancer
}

\author{
Hyeon Seok Oh ${ }^{\mathbb{D}}$, Gyeong Hwa Jeon, and Hyung Kwon Byeon $\mathbb{D}^{\mathbb{D}}$ \\ Department of Otorhinolaryngology-Head and Neck Surgery, Soonchunhyang University College of Medicine, Seoul, Korea
}

\section{구인두암 환자에서 술후 동시화학방사선요법을 시행한 후 발생한 다발성 인두피부누공 1예}

오현석 · 전경화 · 변형권

순천향대학교 의과대학 서울병원 이비인후과학교실

Received February 8, 2021

Revised March 17, 2021

Accepted March 18, 2021

Address for correspondence

Hyung Kwon Byeon, MD, PhD

Department of Otorhinolaryngology-

Head and Neck Surgery,

Soonchunhyang University

College of Medicine,

59 Daesagwan-ro, Yongsan-gu,

Seoul 04401, Korea

Tel $+82-2-709-9364$

Fax $+82-2-709-9362$

E-mail ewellcastle@gmail.com
Pharyngocutaneous fistula is a readily encountered complication that occurs after surgery for laryngopharyngeal cancer. The development of pharyngocutaneous fistula increases hospitalization, delays postoperative adjuvant treatment, and can lead to serious complications such as wound infection and carotid artery rupture. Transoral robotic surgery (TORS) is actively being performed as a standard procedure for surgery of pharyngeal and laryngeal cancers. Many reports verified that TORS is advantageous in terms of perioperative outcomes such as decreased hospitalization and reduced rate of postoperative complications, free flap reconstruction, and tracheostomy or gastrostomy tube dependence relative to open surgery. However, careful selection of patients is mandatory and there are some critical points to consider in optimal treatment outcomes. Recently, we experienced a 47-year-old patient with tonsillar cancer who underwent lateral oropharyngectomy by TORS and radical neck dissection. Unfortunately, multiple pharyngocutaneous fistulae occurred following postoperative concurrent chemoradiotherapy (CCRT). Multiple phrayngocutaneous fistulae following TORS and postoperative CCRT have not been reported in the literature. Therefore, we report this case with a brief discussion supported by a review of the relevant literature.

Korean J Otorhinolaryngol-Head Neck Surg 2021;64(8):592-8

Key Words Oropharyngeal cancer · Pharyngocutaneous fistula $\cdot$ Radiotherapy ·

Transoral robotic surgery.

\section{서 론}

인두피부누공은 두경부암 중에서 주로 후두암과 하인두암 의 술후 발생하는 합병증으로, 약 $5.7 \%$ 65.5\%까지 다양하게 보고되고 있다. ${ }^{1,2)}$ 항생제와 술기의 발달로 인두피부누공의 발생 빈도가 줄고 있는 추세이나, 보존적 치료에 대한 수요가 늘어남에 따라 방사선 치료와 항암제 치료를 시행하는 경우

This is an Open Access article distributed under the terms of the Creative Commons Attribution Non-Commercial License (https://creativecommons.org/licenses/by-nc/4.0) which permits unrestricted non-commercial use, distribution, and reproduction in any medium, provided the original work is properly cited.
가 많아져서 오히려 발생 빈도가 늘어난다는 보고도 있다. ${ }^{3)}$ 인두피부누공의 발생은 입원기간을 늘려 이에 따른 경제적 부담을 증가시키고, 창상 감염이나 경동맥 파열과 같은 중대 한 합병증을 일으킬 수 있기 때문에 신속한 진단과 올바른 처치가 무엇보다 중요하다. ${ }^{4,5}$

경구강 로봇 수술은 Hockstein 등6)이 2005년에 처음으로 다빈치 로봇(da Vinci robot, Intuitive Surgical Inc., Sunnyvale, $\mathrm{CA}, \mathrm{US}$ )을 이용하여 부분 인두후두절제술을 시행한 것을 보고한 이래, 인후두의 악성 종양을 제거함에 있어 하 나의 표준 술식으로서 활발히 시행되고 있다. 구인두암 치료 
에 있어서, 경구강 로봇수술은 기존의 개방 수술(open surgery)과 비교하여 짧은 재원기간, 유리 피판 재건술의 감소, 기관절개술과 위루관 형성의 필요성 감소, 출혈이나 누공 등 의 수술 후 합병증의 감소 등을 보이며, 또한 구인두암에 대 한 근치적 항암방사선 치료와 비교하였을 때 경구강 로봇 수 술은 항암방사선 치료와 유사한 치료 후 연하 기능 결과를 보이는 동시에, 항암방사선 치료에 비해 낮은 위루관 의존성 을 보인다. ${ }^{7)}$

이처럼 최소침습적이고 수술 후 이환율을 최소화할 수 있 는 경구강 로봇 수술이지만, 저자들은 최근에 경구강 로봇 수 술을 시행한 편도암 환자에서 수술 후 창상 회복이 완료되어 동시항암방사선 치료를 시행한 후 추적 관찰 중, 새로 발생한 다발성 인두피부누공을 경험하였기에 본 증례를 문헌 고찰과 함께 보고하는 바이다.

\section{증 례}

47세 남자 환자가 3일 전부터 발생한 좌측 턱 부위의 부종 이 있어 본원 이비인후과 외래로 내원하였다. 과거력상 30갑 년의 흡연력, 당뇨 과거력이 있었고, 최근 6 개월간 $10 \%$ 체중 감소를 호소하였다. 신체검진상 좌측 경부 level II, III에 걸쳐 서 단단하고 고정성의 종물이 다발성으로 촉진되었고, 좌측 편도와에 ulcerofungating 양상의 종물을 포함한 편도 비대 가 관찰되어 외래에서 국소마취하에 조직검사를 시행한 결과, $\mathrm{p} 16$ 양성 편평세포암종이 보고되었다. 이후 시행한 영상검사 상, 경부 전산화단층촬영 및 자기공명영상에서 좌측 편도와 에 국한된 장경 $3.6 \mathrm{~cm}$ 크기의 종물 및 좌측 경부 level II, III에 장경 $6 \mathrm{~cm}$ 이하의 다발성의 림프절 비대 및 응집 소견 이 확인되었으나 전신 양전자단층촬영 검사상 원격 전이 소
견은 보이지 않았다(Fig. 1). The American Joint Committee on Cancer 8판에 따라 cT2N1M0 병기의 편도암 의심하 에 환자의 젊은 나이와 치료 후 사회적 활동을 고려하여 경 구강 로봇 수술과 근치적 경부절제술을 계획하였다.

전신마취 후에, 좌측 경부 level I-V를 포함하는 근치적 경 부절제술을 시행하고, 이어서 다빈치 로봇을 이용한 경구강 접근으로 연구개와 구인두 후벽, 설근부 일부를 포함하여 외 측구인두절제술을 시행하였다(Fig. 2). 수술 당시에 구인두와 경부로 이어지는 수술 부위의 결손은 육안적으로 확인되지 않았으나 잔존 조직이 매우 얇을 것으로 판단하여, 경부 수술 부위의 level I, II 구역을 주변 근조직 및 연조직을 이용하여 보강하고 추가로 Tisseel(대한적십자사, Seoul, Korea) 등으로 도포하고 수술을 종료하였다. 수술 직후 환자는 금식을 유지 하고 있다가 수술 후 9일째 경구식이를 처음 시작하였는데, 시작과 동시에 경부절제술 부위의 배액관으로 타액 유출이 확인되었다. 환자의 헤모글로빈은 수술 전 $15.3 \mathrm{~g} / \mathrm{dL}$ 에서 수 술 후 $12.3 \mathrm{~g} / \mathrm{dL}$ 로 감소하였으며, 알부민은 수술 전 $5.0 \mathrm{~g} / \mathrm{dL}$ 에서 수술 후 $3.9 \mathrm{~g} / \mathrm{dL}$ 로 감소한 소견이 있었다. 따라서 정맥 항생제 요법 및 금식 유지, 압박 드레싱 등의 보존적인 요법을 시행하였고, 수술 후 19 일째 누공 소실되어 경구식이를 다시 시작하고 점진적으로 늘려 특이 문제가 보이지 않아 퇴원하 였다. 이후 외래에서 추적 관찰 중 인두 점막의 상태가 양호 한 것을 확인하고 종양내과와 방사선종양학과와 상의하여 퇴원 3주 후 술후 동시항암방사선 치료를 시행하였다.

환자는 술후 동시항암방사선 치료 종료 6주 후부터 호흡 곤란 증상을 호소하여 방사선으로 인한 후두염 진단하에 3차 례 입원 후 보존적인 치료를 하고 퇴원하였다. 이후 정기적 외래 추적 관찰 중 술후 동시항암방사선 치료 종료 후 21 주 째, 좌측 경부 level II에 작은 피부 결손 부위와 함께 혼탁성
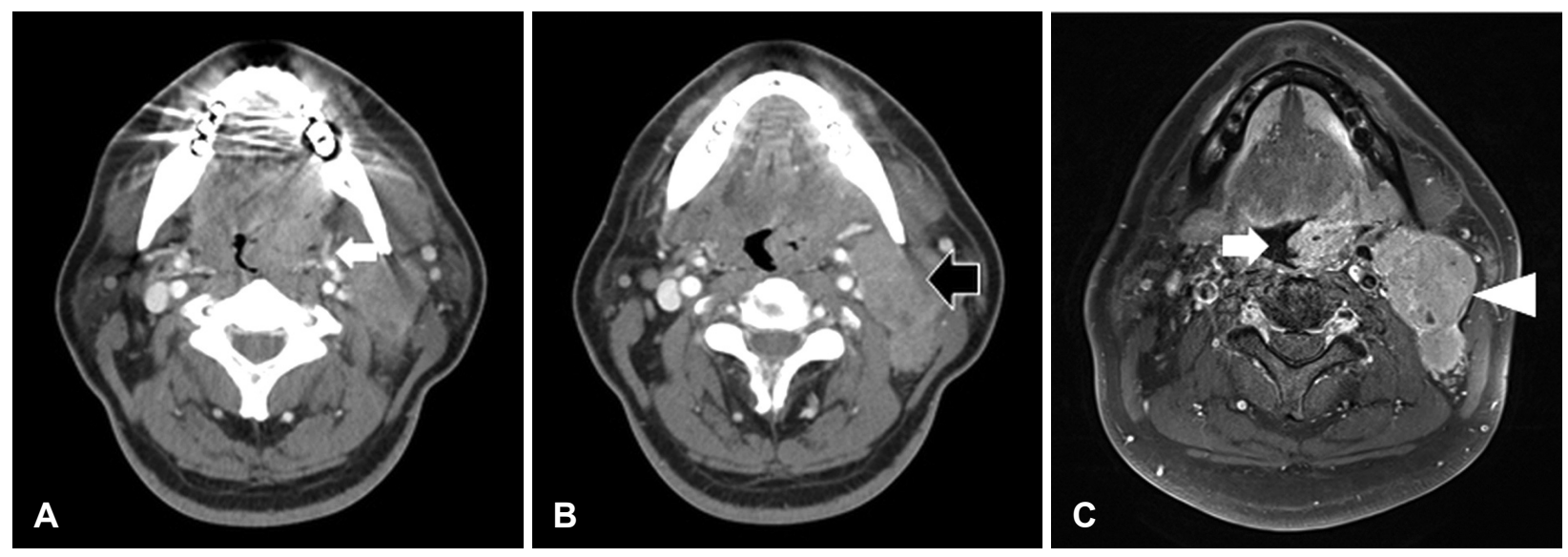

Fig. 1. Preoperative axial CT and MR findings. About $3.6 \times 1.4 \times 3.2 \mathrm{~cm}$ sized large enhancing mass was seen at left palatine tonsil $(A$ : arrow, CT; C: arrow, T1W enhanced MRI) and multiple enhancing conglomerated ipsilateral lymph nodes measuring up to $6 \mathrm{~cm}$ were seen at left levels II and III (B: arrow, CT; C: arrowhead, T1W enhanced MRI). T1W: T1-weighted. 
삼출물이 흘러나오는 것을 발견하였고, 당시 시행한 경부 전 산화단층촬영 검사에서, 이전에는 보이지 않던 좌측 편도와 에서 좌측 부인두공간으로 연결된 누공이 새로 형성된 것을 확인하였다(Fig. 3). 이에 따라 국소마취하 절개 배농술을 시 행한 뒤, 피부 결손 부위에서 구인두 공간까지 이어지는 누공 길(fistulous tract)을 확인한 이후, 배액관의 도관을 재단하 고 경부에서 구인두 방향으로 이를 거치하여 지속적 음압 드 레싱을 시행하였고, 이와 함께 비영양관 튜브를 통한 식사 및 정맥 내 항생제 치료를 시행하였다(Fig. 4). 치료를 유지하여 1 달 뒤 시행한 경부 전산화단층촬영 검사에서 인두피부누공 이 호전되지 않은 것을 확인하였고, 이에 따라 전신마취하 대 흥근피판을 이용하여 결손 부위를 재건하였다(Fig. 5). 수술 후 8일째 금식과 정맥 내 고영양 치료를 유지하던 중, 환자가 협조하지 않아 소량의 경구식이를 시작하였다. 수술 후 12 일 째 수술 부위 배액관을 통해 다시 타액이 유출되는 것을 확 인하여 전신마취하에 경부 탐색술을 시행하였고, 피판 부위 는 유지되고 있는 것을 확인하여 죽은조직제거술을 시행한
후 수술을 종료하였다. 환자는 금식을 다시 유지하였고 대흥 근 피판재건술 이후 38 일째 식도조영술을 시행하였으며, 좌측 이상와 부위에서 작은 누공이 추가로 확인되었으나(Fig. 6), 환자가 경구식이를 강하게 희망하여 2일 후 소량의 경구식이 를 재개하였다. 이후 배액관의 배액량이 줄어드는 양상을 보 이는데다 환자가 외래 통원치료를 희망하여 입원한 후 80일 만에 배액관을 유지한 채로 퇴원하였다.

퇴원 이후 3 주째 외래에서 추적 관찰 중, 신체 진찰상 첫 누공 발생 부위와 별도로 좌측 쇄골상 경부 부위의 발적 및 부종이 발견되어 시행한 세침 흡인상 혼탁한 배액이 확인되 었다. 전신마취하 경부 탐색술을 시행하였고, 경구강을 통해 인두 부위를 확인하였지만 구인두 부위에는 누공이 의심되 는 소견은 보이지 않았다. 피부쪽 누공 입구를 통해 배액관 을 삽입 후 지속적인 음압을 유지하며 드레싱 치료와 항생제 치료, 정맥 내 고영양 치료를 시행하였다. 수술 후 8일째 경구 식이를 시작하였고, 9일째 식도조영술을 시행한 결과 좌측 이상와의 누공과 함께 동측의 편도와 부위의 작은 누공 입
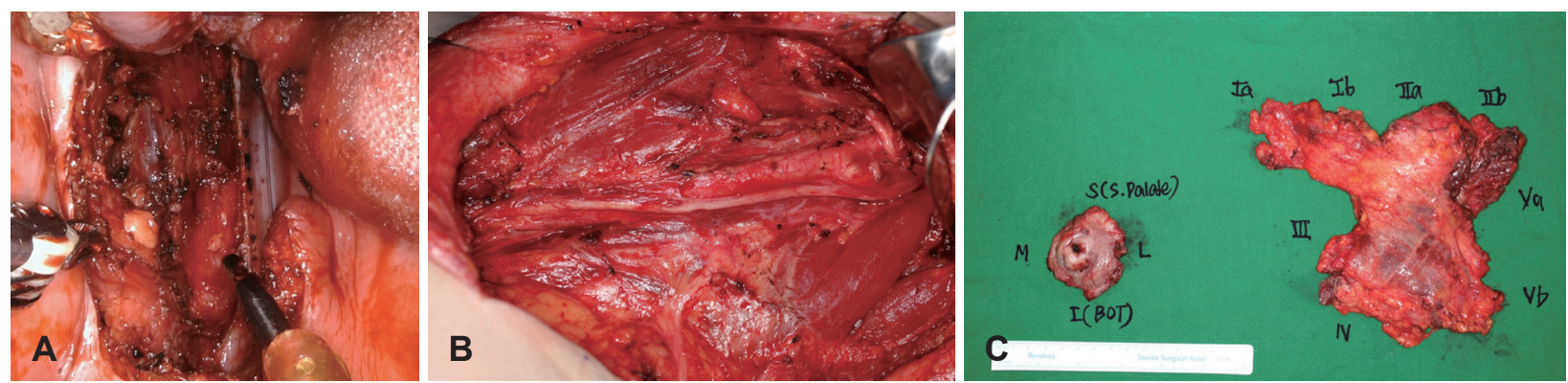

Fig. 2. Operative photographs. Surgical view of transoral robotic surgery during lateral oropharyngectomy (A). Operative field after radical neck dissection (L) (B). Surgical specimen (C). L: left.
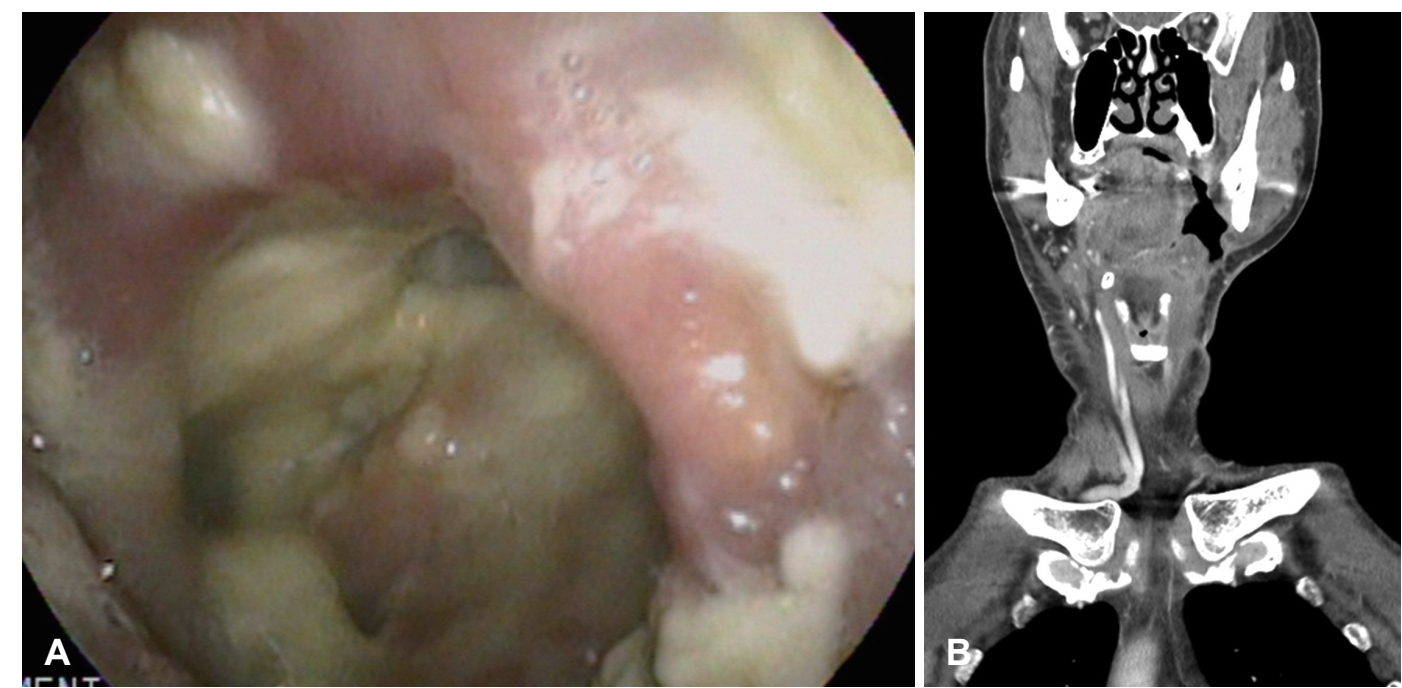

Fig. 3. Pharyngocutaneous fistula at left lateral oropharyngectomy site. Endoscopic finding showing defective lesion with opening of pharyngocutaneous fistula at previous left lateral oropharyngectomy site (A). Coronal view images from neck CT showing fistula formation from left mouth floor extending to parapharyngeal cervical space (B). 
구가 아직 확인되었다(Fig. 7). 수술 후 13일째 압박드레싱을 유지한 채로 퇴원하였다.

퇴원 후 3일째 외래 추적 관찰 중, 이전의 경부 level II 피부 누공 위치보다 상방에 새로운 누공 입구가 발생한 것을 확인 하여 국소마취하 절개 배농술 시행 후 배액관을 삽입하였고, 경구식이는 유지하며 압박드레싱을 시행하여 배농술을 시행 한지 6주 후에 누공 입구가 막힌 것을 확인하였다(Fig. 8). 누 공 입구가 막힌 뒤 외래 추적 관찰 중 2주째, 동일 부위에 인

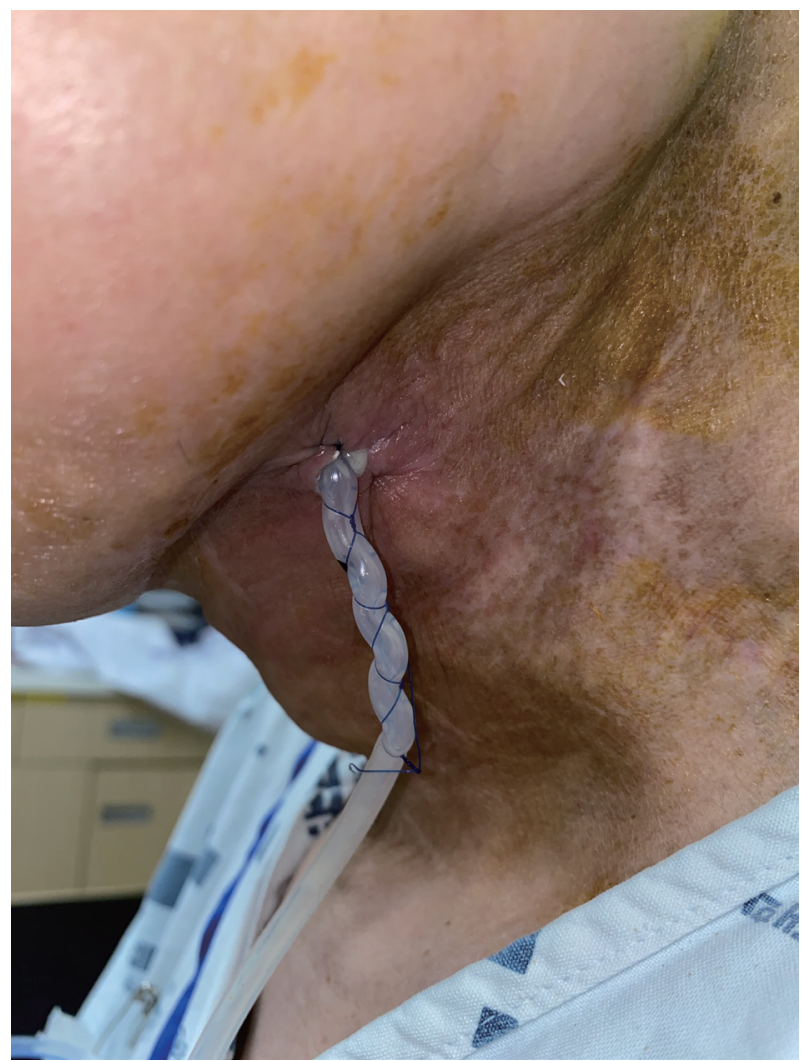

Fig. 4. Continuous negative drainage from opening of pharyngocutaneous fistula.

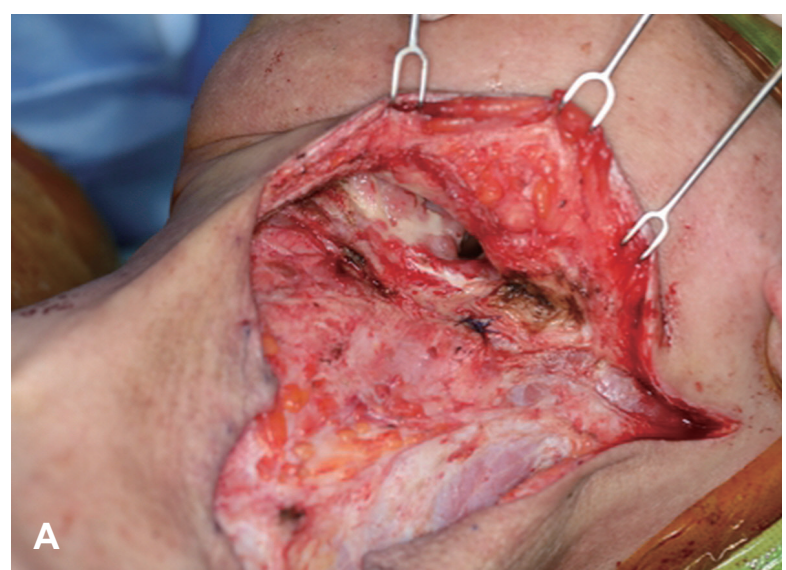

두피부누공이 재발하여 외래에서 국소마취하 절개 배농술을 다시 시행하였고, 압박드레싱을 시행한 후 5주째 누공이 완전 히 막혀 치료를 종료하였다. 치료 종료 후 2주째 시행한 경부 전산화단층촬영 검사상 구인두에서 후인두공간으로 이어지 는 누공과 좌측 구인두에서 좌측 악하공간으로 이어지는 누 공이 사라진 상태가 확인되었다(Fig. 9). 이후 13주까지 추가 누공 발생 없이 잘 막힌 상태로 유지하며 경과 관찰 중이다.

\section{고 찰}

인두피부누공은 인후두암 등의 두경부암 수술 후 주로 7 10일째 발견되며, 누공의 조기발견이 환자의 치료 경과에 영향을 미치기에 면밀한 관찰이 필요하다. ${ }^{8)}$ 인두피부누공의 위험인자로는 수술 전 방사선 치료 유무, 수술 중 경부절제술 시행 유무, 종양의 병기, 수술 후 헤모글로빈 수치, 수술 후 알

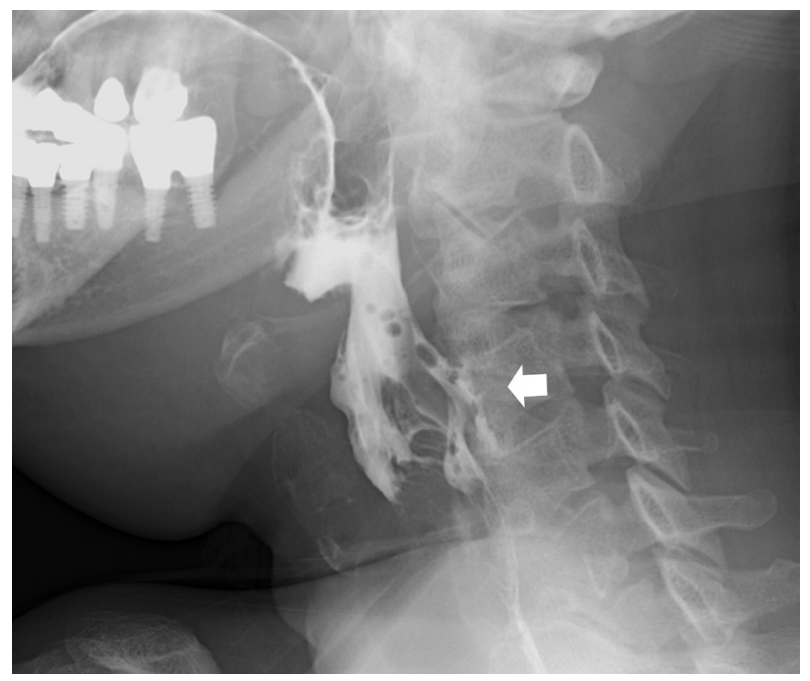

Fig. 6. Pharyngoesophagogram with gastrografin showing leakage of contrast media at left pyriform sinus (arrow).

Fig. 5. Pectoralis major myocutaneous flap reconstruction for pharyngocutaneous fistula. Large tissue defect was noted at level I, II extending to ipsilateral floor of mouth (A). Operative photograph after reconstruction of defect with pectoralis major myocutaneous flap (B). 
부민 수치 등이 있다. ${ }^{9}$ 인두피부누공의 의심 소견으로는 누공 부위의 발적 및 부종, 원인 미상의 발열, 배액관의 혼탁한 배 액, 썩는 냄새, 경부 단순 촬영에서의 가스 음영 등의 소견과 함께 배액의 높은 amylase 수치 등이 있다. ${ }^{10)}$ 이런 이상 소견 이 보일 경우, 식도 조영술을 하거나 메틸렌 블루를 삼키는 검사를 통해 인두피부누공을 확진할 수 있다. ${ }^{11)}$ 타액 누공이 발생하였을 경우, 누공 부위를 조정하여 분비물을 우회하여 지속적으로 배액시키고 비위관을 통해 영양을 공급하면서 경구식이를 제한하고, 혐기성 균에 작용하는 항생제를 사용 해야 한다. 수술 부위의 타액 저류를 방지하기 위하여 구강

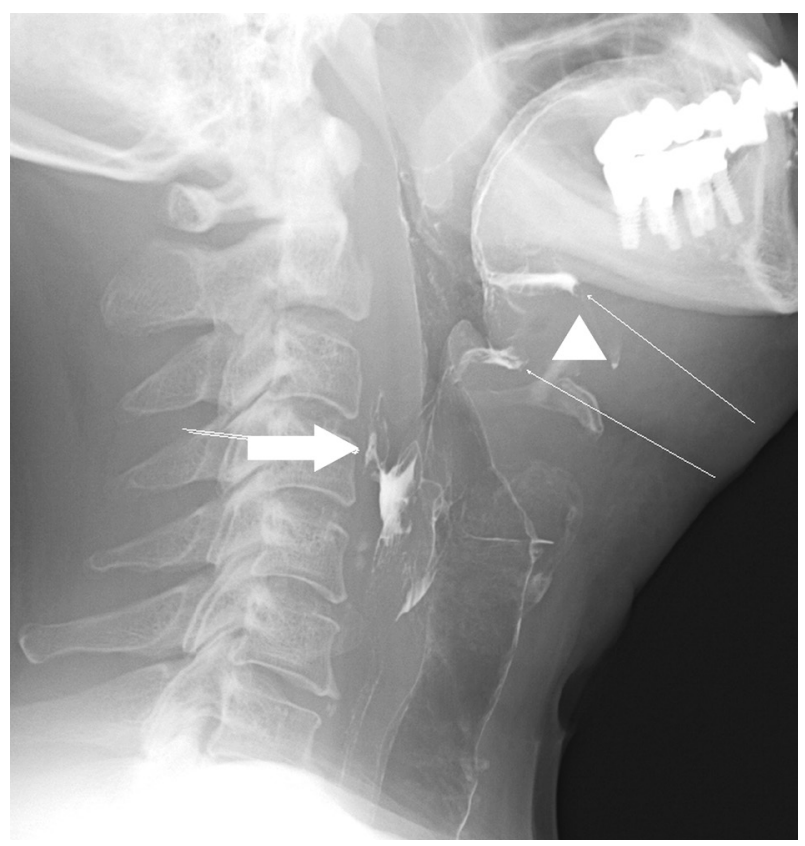

Fig. 7. Pharyngoesophagogram with gastrografin showing multiple fistulae with leakage of contrast media at left pyriform sinus (arrow) and left tonsillar fossa (arrowhead).
과 인두 내의 지속적인 음압 배액관을 거치시키는 방법 또한 효과적일 수 있다. ${ }^{2)}$ 작은 크기의 누공은 일차 봉합을 통해 치료해 볼 수 있으나, 누공의 크기가 클 경우에는 인공 누공 (controlled fistula)을 만들거나 피판술을 시행해야 하는 경 우도 있다. ${ }^{9,13)}$

본 증례에서는 초치료로서의 수술 이후 9일째 경구식이 개시 직후 수술 부위의 누공이 발생하여 정맥 항생제 요법 및 금식, 압박 드레싱을 통해 누공이 소실되고 조직이 치유된

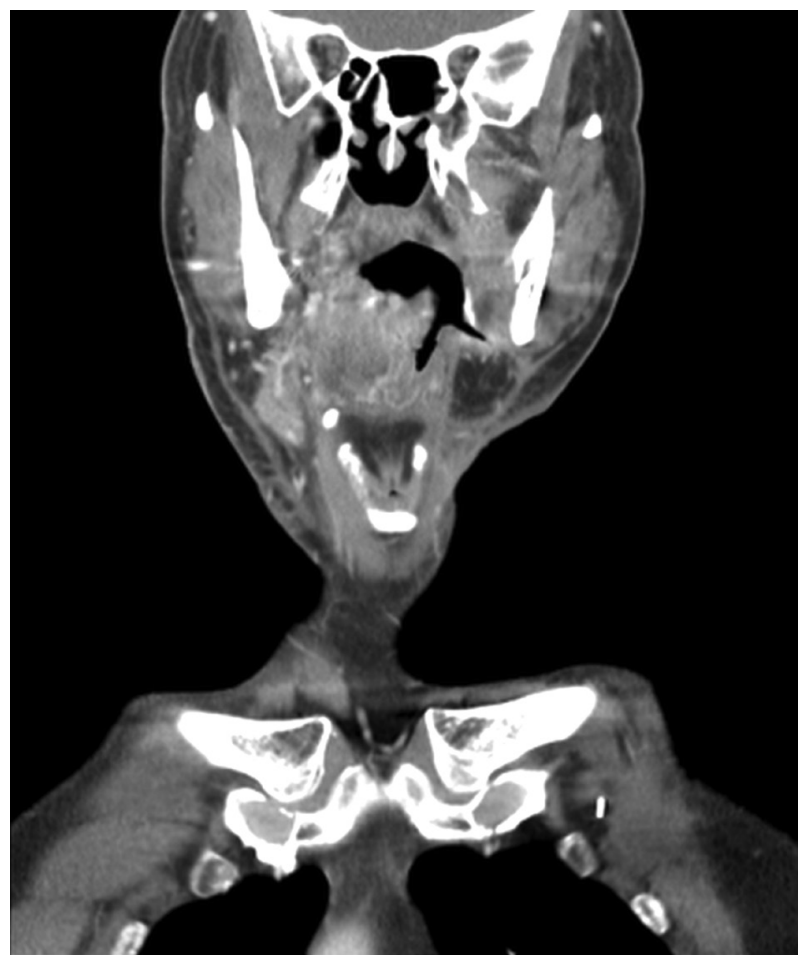

Fig. 9. Coronal view images of neck CT showing dissolution of pharyngocutaneous fistula with improvement of soft tissue defect between left oropharynx and submandibular space.
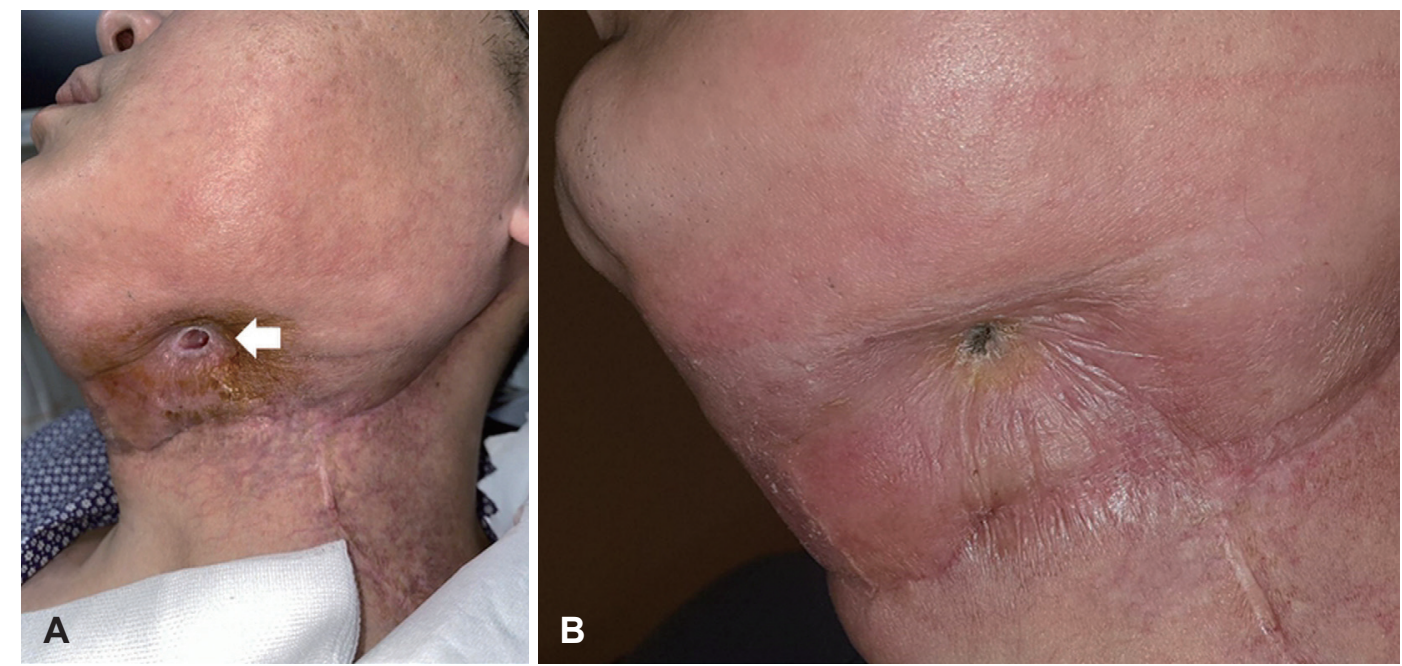

Fig. 8. Pharyngocutaneous fistula at left neck. Opening of newly developed pharyngocutaneous fistula (A). Healed fistulous opening after dressing (B). 
것을 확인 후 퇴원하였으나, 술후 항암방사선 치료 종료 후 21 주째, 수술 이후 6개월째 외래 추적 관찰 중 구인두 및 하 인두 부위의 동시다발성 인두피부누공이 발생한 증례이다. 기존의 여러 문헌 보고에서 술전 방사선치료를 받은 환자에 서 수술 후 인두피부누공이 발생한 경우가 많았으나, 본 증례 에서는 수술 후 조직의 회복은 양호하였으나 술후 항암방사 선 치료 후 발생한 인두피부누공으로서, 방사선 치료가 누공 발생에 큰 영향을 미쳤을 것으로 추정된다. 인두피부누공이 발생한 초기에는 경부 전산화단층촬영 검사를 시행한 후, 편 도암의 원발 부위인 구인두 부위에서의 누공만을 고려하고 하인부 부위 누공을 고려하지 않고 치료를 시작하였고, 항암 방사선 치료 종료 후 27주째 대흥근 피판술을 한 뒤 시행한 식도 조영술에서 하인두 부위의 누공을 비로소 발견하여 이 로 인해 단기간에 인두피부누공이 치료되기 어려웠던 것으 로 추정된다. 뿐만 아니라 환자가 수술과 방사선 치료로 인해 개구장애를 보이고 있어 대흥근 피판술 재건술 당시 구강을 통한 접근으로는 구인두 부위 결손 부위의 완벽한 재건이 어 려웠던 점, 환자가 자의로 식이를 조기에 시작했던 점도 창상 회복 지연의 요인으로 작용한 것으로 보인다. 이처럼 인두피 부누공의 치료가 지연되고 어려운 경우, 여러 경우를 염두에 두어야 할 것이다.

Parazefall 등 ${ }^{14}$ 에 의하면 67 명의 후두 및 하인두 편평상피 세포암 환자에서 후두인두절제술과 양측 경부절제술 시행과 함께 수술 후 보조 방사선 치료를 시행하였고, 수술 후 인두 피부누공이 발생한 경우 수술 후 방사선 치료의 시작이 유의 미하게 지연된다고 보고하였다. 또한 수술 후 6주 이후에 방 사선 치료를 시작할 경우, 조기에 방사선 치료를 시작할 경우 와 비교하였을 때 생존율이 낮다고 보고하였고, 인두피부누 공이 발생하였던 2 명 환자의 경우에서는 누공이 있는 상태로 방사선 치료를 시작하였고, 방사선 치료 중 누공이 자연적으 로 폐쇄되었던 경우도 보고하였다. 본 증례에서는 환자가 첫 번째 수술을 시행하고 일시적으로 누공이 발생하였지만 보 존적 치료를 통해 누공을 치료하였고, 신체 진찰 소견상 더 이상의 타액 유출이나 누공 소견은 보이지 않고, 인후두의 점막 상태가 양호한 것을 확인하고, 수술 후 6주가 되기 전인 40 일째에 보조 항암방사선 치료를 시작하였다. 본 증례와는 다르지만 수술 후 누공이 발생하여 누공의 치료가 완전히 되 지 않은 상태라 하더라도, 수술 후 보조 항암방사선 치료를 계획하고 있다면 항암방사선 치료의 시작이 지연될수록 예후 에 나쁜 영향을 줄 수 있음을 인지하고, 늦어도 수술 후 6주 이전에는 항암방사선 치료 시작을 고려해봐야 할 것으로 생 각한다.

de Almeida 등 ${ }^{15)}$ 은 초기 $\mathrm{T}$ 병기의 구인두암 환자 772 명에
대하여 경구강 로봇 수술 시행 후 발생한 부작용으로 출혈 (2.4\%), 누공(2.5\%) 등을 보고하였고, 수술을 시행한 환자에 서 보조 방사선 치료(26\%), 항암방사선치료(41\%)가 필요했다 고 보고하였다. Moore 등 ${ }^{16}$ 은 66명의 구인두암으로 진단받은 환자에서 경구강 로봇 수술을 시행한 후 4 명에서 인두피부누 공이 발생하였고, 4 명 모두 수술적 치료를 시행하지 않고 압 박드레싱을 통해 치료를 하였다고 보고하였다. Cannon 등ㄱ) 은 88명의 HPV 양성 구인두암 환자에 대하여 경구강 로봇 수술과 경부 level II-IV에 대하여 경부절제술을 시행하였고, 2 명에서 수술 중 인두피부누공이 발생하였지만, 국소 이복근 피판술로 재건을 한 결과 수술 후 발생한 인두피부누공의 환 자는 없었다. 경부절제술 시에 level Ib를 보존하는 것이 수 술 중 인두피부누공이 발생하더라도 최소한의 재건술만으로 수술 후 인두피부누공의 예방에 도움이 된다고 보고하였다.

Weinstein 등 ${ }^{18)}$ 은 경구강 로봇 수술을 시행함에 있어서 종 양의 위치와 주변 해부학적 구조를 고려하여 혈관, 기능, 종 양 등 세 가지 범주의 금기증을 제시하였다. 혈관 요인으로는 후인두 경동맥이 침범된 편도 악성 종양, 종양이 내경동맥이 나 경동맥 전구에 가까이 위치한 경우가 있으며, 기능적 요인 으로는 종양의 절제 범위가 혀의 깊은 근육층 또는 후인두 벽의 $50 \%$ 이상을 요하는 경우, 설근부와 후두개 전체를 절제 해야 하는 경우, 종양학적 요인으로는 T4b 악성 종양, 다발성 원격 전이, 종양 침범으로 인한 개구 장애, 하악골이나 설골 을 침범한 경우 등이 있다. 다만, 경구강 로봇 수술은 원발 부 위 종양을 제거하는 하나의 수술법으로써, 위에 나열한 경우 를 고려하여 임상적으로 경구강 접근으로 원발 부위 종양을 제거할 수 있는 경우이면 경구강 로봇 수술을 시행할 수 있 으며, 원발 부위 종양을 제거한 이후 재건이 필요한 경우가 본 술식의 절대적인 금기증은 아닐 것이다. Williamson 등'19)은 본 증례와 같이 구인두암 환자에서 경구강 로봇 수술을 시행 한 이후에는 경부절제술 부위와 연결하여 유리 피판술로 재 건이 충분히 가능하다고 보고한 바 있다.

본 증례와 같이 경부 level II에 다발성 림프절이 있어 경부 절제술과 함께 경구강 로봇 수술을 통해 충분한 안전 절제연 을 두고 원발 부위 종양을 제거한다면, 경부와 인두점막 사 이의 결손이 발생할 가능성이 높고, 술후 동시항암방사선 치 료를 시행한다면 인두피부누공 발생의 가능성은 더욱 높아 질 것이다. 이번 증례를 통해서 구인두암 환자에서 경구강 로 봇 수술과 경부절제술을 시행한 후, 술후 동시항암방사선 치 료까지 예상되는 경우에 누공 발생을 예방하기 위해서 인두 피판, 볼지방체 피판, 안면 동맥 피판 등의 국소피판이나, 흥 쇄유돌근 피판, 이복근 피판, 또는 유리 피판술로 선제적으로 재건을 하거나, 가능할 경우 경부절제술 시에 경부 level Ib를 
보존하는 술식을 고려하는 것이 특별히 더 중요할 것으로 생 각된다.

본 증례에서는 대흥근피판 재건술을 포함하여 수차례의 보 존적 절개 배농 및 지속적 음악 배액 등을 반복적으로 시행 하여 인두피부누공이 처음 발생한지 33주 만에 누공 부위가 모두 막혀 치료를 종결하였다. 저자들은 이번 증례를 통하여 술후 동시항암방사선 치료 이후에도 인두피부누공이 발생할 수 있기 때문에 정기적인 외래 추적 관찰 시에 면밀한 신체 진찰이 필요할 것으로 생각되며, 인두피부누공의 치료가 지 연될 경우 타부위에서의 다른 인두누공의 발생 가능성을 고 려하는 것이 치료에 중요하다는 것을 경험하였다. 또한 수술 이후 방사선 치료 혹은 동시항암방사선 치료가 예상되는 환 자에서 경구강 로봇 수술 후 누공 발생 가능성이 예상되는 경우, 경부절제술 시에 경부 level Ib를 보존하거나 국소 또는 유리 피판술로 결손 부위를 재건하는 것을 반드시 고려해야 할 것이다.

\section{Acknowledgments}

None.

\section{Author Contribution}

Conceptualization: Hyung Kwon Byeon. Writing —original draft: Hyeon Seok Oh, Gyeong Hwa Jeon. Writing—review \& editing: Hyung Kwon Byeon.

\section{ORCIDs}

Hyung Kwon Byeon https://orcid.org/0000-0003-3709-2028

Hyeon Seok Oh https://orcid.org/0000-0001-9361-0569

\section{REFERENCES}

1) Akyol MU, Ozdem C, Celikkanat S. Early oral feeding after total laryngectomy. Ear Nose Throat J 1995;74(1):28-30.

2) Johansen LV, Overgaard J, Elbrønd O. Pharyngo-cutaneous fistulae after laryngectomy. Influence of previous radiotherapy and prophylactic metronidazole. Cancer 1988;61(4):673-8.

3) Grau C, Johansen LV, Hansen HS, Andersen E, Godballe C, Andersen LJ, et al. Salvage laryngectomy and pharyngocutaneous fistulae after primary radiotherapy for head and neck cancer: A national survey from DAHANCA. Head Neck 2003;25(9):711-6.

4) Choi EC, Cho CH, Lee SM, Kim YH, Hong WP. Pharyngocutaneous fistula after total laryngectomy. Korean J Otorhinolaryngol-Head Neck Surg 1995;38(9):1427-33.

5) Lebo NL, Caulley L, Alsaffar H, Corsten MJ, Johnson-Obaseki S.
Peri-operative factors predisposing to pharyngocutaneous fistula after total laryngectomy: Analysis of a large multi-institutional patient cohort. J Otolaryngol Head Neck Surg 2017;46(1):54.

6) Hockstein NG, Nolan JP, O'Malley BW Jr, Woo YJ. Robot-assisted pharyngeal and laryngeal microsurgery: Results of robotic cadaver dissections. Laryngoscope 2005;115(6):1003-8.

7) Parikh A, Lin D, Goyal N. Clinical outcomes of transoral roboticassisted surgery for the management of head and neck cancer. Robotic Surgery: Research and Reviews 2015;2:95-105.

8) Mäkitie AA, Irish J, Gullane PJ. Pharyngocutaneous fistula. Curr Opin Otolaryngol Head Neck Surg 2003;11(2):78-84.

9) Do SB, Chung CH, Chang YJ, Kim BJ, Rho YS. Risk factors of and treatments for pharyngocutaneous fistula occurring after oropharynx and hypopharynx reconstruction. Arch Plast Surg 2017;44(6):530-8.

10) Genden EM, Rinaldo A, Shaha AR, Bradley PJ, Rhys-Evans PH, Ferlito A. Pharyngocutaneous fistula following laryngectomy. Acta Otolaryngol 2004;124(2):117-20.

11) Giordano AM Jr, Cohen J, Adams GL. Pharyngocutaneous fistula after laryngeal surgery: The role of the barium swallow. Otolaryngol Head Neck Surg 1984;92(1):19-23.

12) Chang HP, Hong JW, Lee WJ, Kim YS, Koh YW, Kim SH, et al. Incorporating a continuous suction system as a preventive measure against fistula-related complications in head and neck reconstructive surgery. Arch Plast Surg 2018;45(5):449-57.

13) Rho YS, Kim CH, Jin JW, Kim JH, Ahn HY, Chung CH. Clinical analysis of pharyngocutaneous fistula after total laryngectomy. Korean J Otorhinolaryngol-Head Neck Surg 2007;50(11):1023-9

14) Parzefall T, Wolf A, Grasl S, Altorjai G, Czeiger S, Grasl MC, Erovic BM. Post-laryngectomy adjuvant radiotherapy in patients with pharyngocutaneous fistulae: Treatment regimens, outcomes and complications in 67 patients. Clin Otolaryngol 2019;44(5):810-4.

15) de Almeida JR, Byrd JK, Wu R, Stucken CL, Duvvuri U, Goldstein $\mathrm{DP}$, et al. A systematic review of transoral robotic surgery and radiotherapy for early oropharynx cancer: A systematic review. Laryngoscope 2014;124(9):2096-102.

16) Moore EJ, Olsen SM, Laborde RR, García JJ, Walsh FJ, Price DL, et al. Long-term functional and oncologic results of transoral robotic surgery for oropharyngeal squamous cell carcinoma. Mayo Clin Proc 2012;87(3):219-25.

17) Cannon RB, Houlton JJ, Patel S, Raju S, Noble A, Futran ND, et al. Patterns of cervical node positivity, regional failure rates, and fistula rates for HPV+ oropharyngeal squamous cell carcinoma treated with transoral robotic surgery (TORS). Oral Oncol 2018;86:296300.

18) Weinstein GS, O’Malley BW Jr, Rinaldo A, Silver CE, Werner JA, Ferlito A. Understanding contraindications for transoral robotic surgery (TORS) for oropharyngeal cancer. Eur Arch Otorhinolaryngol 2015;272(7):1551-2.

19) Williamson A, Haywood M, Awad Z. Feasibility of free flap reconstruction following salvage robotic-assisted resection of recurrent and residual oropharyngeal cancer in 3 patients. Ear Nose Throat J 2020:145561320937627. 